\title{
Cytoprotective effects of silafibrate, a newly-synthesised siliconated derivative of clofibrate, against acetaminophen-induced toxicity in isolated rat hepatocytes
}

\author{
Sara Nafisi ${ }^{1,2,3,4}$, Reza Heidari ${ }^{5}$, Mohammad Ghaffarzadeh ${ }^{6}$, Mojtaba Ziaee ${ }^{1,2}$, Hossein Hamzeiy ${ }^{1,3}$, \\ Alireza Garjani²,3, and Mohammad Ali Eghbal2,3 \\ Biotechnology Research Centerl, Drug Applied Research Center', Pharmacology and Toxicology Department, School \\ of Pharmacy ${ }^{3}$, Students' Research Committee, Tabriz University of Medical Sciences, Tabriz, Pharmaceutical Sciences \\ Research Center (PSRC), Shiraz University of Medical Sciences, Shiraz, Iran ${ }^{5}$, Chemistry and Chemical Engineering \\ Research Center of Iran, Tehran ${ }^{6}$, Iran
}

Received in August 2013

CrossChecked in August 2013

Accepted in January 2014

\begin{abstract}
Acetaminophen (N-acetyl para amino phenol, APAP) is a widely used antipyretic and analgesic drug responsible for various drug-induced liver injuries. This study evaluated APAP-induced toxicity in isolated rat hepatocytes alongside the protective effects of silafibrate and N-acetyl cysteine (NAC). Hepatocytes were isolated from male Sprague-Dawley rats by collagenase enzyme perfusion via the portal vein. This technique is based on liver perfusion with collagenase after removing calcium ions $\left(\mathrm{Ca}^{2+}\right)$ with a chelator. Cells were treated with different concentrations of APAP, silafibrate, and NAC. Cell death, reactive oxygen species (ROS) formation, lipid peroxidation, and mitochondrial depolarisation were measured as toxicity markers. ROS formation and lipid peroxidation occurred after APAP administration to rat hepatocytes. APAP caused mitochondrial depolarisation in isolated cells. Administration of silafibrate $\left(200 \mu \mathrm{mol} \mathrm{L}^{-1}\right)$ and/or NAC $\left(200 \mu \mathrm{mol} \mathrm{L}^{-1}\right)$ reduced the ROS formation, lipid peroxidation, and mitochondrial depolarisation caused by APAP. Cytotoxicity induced by APAP in rat hepatocytes was mediated by oxidative stress. In addition, APAP seemed to target cellular mitochondria during hepatocyte damage. The protective properties of silafibrate and/or NAC against APAP-induced hepatic injury may have involved the induction of antioxidant enzymes, protection against oxidative stress and inflammatory responses, and alteration in cellular glutathione content.
\end{abstract}

KEY WORDS: drug-induced liver injury (DILI); fibrates; mitochondria; oxidative stress; reactive oxygen species (ROS)

Acetaminophen (N-acetyl para amino phenol, APAP) is a widely used analgesic and antipyretic drug, which if applied excessively can cause severe hepatic damage or even death in experimental animals and individuals (1). At recommended doses, APAP is mainly metabolised by sulphation and glucuronidation (2). A small proportion of APAP is metabolised through cytochrome CYP2E1 and, to a lesser extent, CYP1A2 and CYP3A4, which produce the reactive metabolite N-acetyl-p-benzoquinoneimine (NAPQI).
This reactive intermediate is efficiently detoxified by conjugation with glutathione (3). However, in overdoses, a large amount of APAP is metabolised through the P450 family of cytochromes leading to GSH depletion by NAPQI conjugation followed by the covalent binding of NAPQI to proteins (4). Cellular mitochondria seem to be the target for acetaminophen-induced hepatotoxicity (5).

Although the precise mechanism of APAP hepatotoxicity is not fully understood, some studies 
$(5,6)$ have suggested that NAPQI exerts a cytotoxic effect through its covalent binding to cytosolic or microsomal proteins and membrane components, inducing oxidative stress in cells, inhibition of mitochondrial respiration, and depletion of cellular ATP. Research on acetaminophen-induced hepatotoxicity and finding new approaches to prevent it is a dynamic field of research due to high incidence of hepatotoxicity induced by this drug accidentally or in suicidal attempts $(6,7)$.

Silafibrate (ethyl 2-(4-(trimethylsilyl) phenoxy)2-methylpropanoate) (Figure 1) is a siliconated derivative of the drug clofibrate (8). Fibrates belong to the peroxisome proliferator-activated receptor $\alpha$ (PPAR- $\alpha$ ) drug group, which has been reported to have anti-inflammatory effects (9). Furthermore, PPAR ligands' antioxidant and oxidative stress modulating properties have been shown in previous studies $(10,11)$. It has been reported that the trimethylsilyl group in silafibrate (Figure 1) increases the anti-inflammatory properties of clofibrate and enhances its pharmacological effect on PPAR receptors (8). It has also been shown that PPAR receptors have a crucial role in preventing APAPinduced hepatic damage (12). The role of silafibrate, as a new and more potent analogue of clofibrate (8) against APAP-induced hepatotoxicity in isolated rat hepatocytes was evaluated in this study. The protective role of $\mathrm{N}$-acetylcysteine (NAC) as a gold standard treatment for acetaminophen-induced hepatotoxicity (13), was also studied and compared with silafibrate in this investigation.

Cell death, oxidative stress induction (ROS formation), lipid peroxidation, and mitochondrial injury were assessed as toxicity markers induced by acetaminophen $(5,6)$.
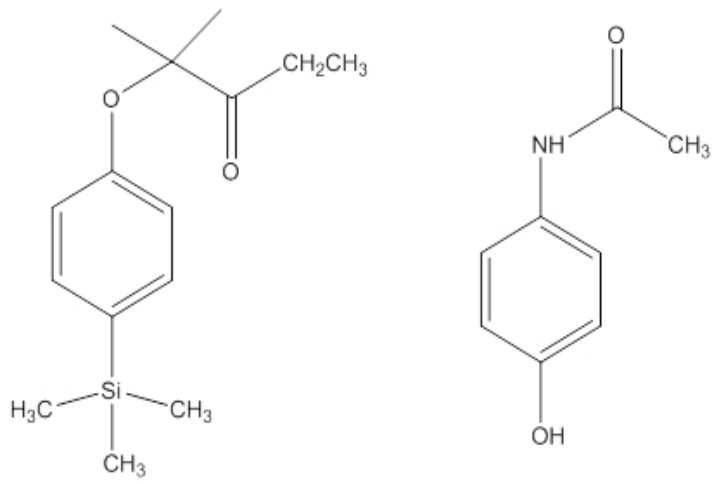

Figure 1 Chemical structure of silafibrate (left) and acetaminophen (right)

\section{MATERIAL AND METHODS}

\section{Chemicals}

Acetaminophen was purchased from Medisca Pharmaceutique Incorporation (Montreal, Canada). $\mathrm{N}$-acetyl cysteine (NAC) and (4-(2-hydroxyethyl) 1-piperazine-ethanessulfonic acid (HEPES) were obtained from Acros (New Jersey, USA). Albumine bovine type was purchased from Roche Diagnostics Corporation (Indianapolis USA). Rhodamine 123 and Collagenase from Clostridium histolyticum were obtained from Sigma Aldrich (St. Louis, MO, USA). Trichloroacetic acid (TCA), ethyleneglycolbis ( $\rho$-aminoethylether)- $\mathrm{N}, \mathrm{N}, \mathrm{N}^{\prime}, \mathrm{N}^{\prime}$-tetra acetic acid (EGTA), and Trypan Blue were obtained from Merck (Darmstadt, Germany). A siliconised analogue of clofibrate, silafibrate, was synthesised in the Chemistry and Chemical Engineering Research Center, Tehran, Iran. Thiobarbituric acid (TBA) was obtained from SERVA (Heidenberg, New York). All salts used for preparing buffer solutions were of analytical grade and obtained from Merck (Darmstadt, Germany).

\section{Hepatocyte preparation}

Male Sprague-Dawley rats (three animals for each test, $\mathrm{N}=15$ ) weighing $250-300 \mathrm{~g}$ were housed in plastic cages at ambient temperature $\left(25 \pm 3^{\circ} \mathrm{C}\right)$. Animals had free access to food and water. Collagenase perfusion method was used to isolate rat hepatocytes (14). This technique is based on liver perfusion with collagenase after the removal of calcium ion $\left(\mathrm{Ca}^{2+}\right)$ with a chelator (EGTA $0.5 \mathrm{~mol} \mathrm{~L}^{-1}$ ). The liver was perfused with different buffer solutions through the portal vein. Collagenase-containing buffer solution destructed liver interstitial tissue and caused hepatocytes to be easily isolated. Isolated hepatocytes $\left(10 \mathrm{~mL}, 10^{6}\right.$ cells $\mathrm{mL}^{-1}$ ) were incubated in the Krebs-Henseleit buffer $(\mathrm{pH} 7.4)$ under an atmosphere of $95 \% \mathrm{O}_{2}$ and $5 \%$ $\mathrm{CO}_{2}$ in $50 \mathrm{~mL}$ round bottom flasks which were continuously rotating in a water bath at $37^{\circ} \mathrm{C}$. For more precise details on isolated rat hepatocytes preparation, readers are referred to Moldéus et al (15). As CYP2E1, the acetaminophen-metabolising enzyme expression is low in rat liver (16), we used the enzyme induction method by administering $\beta$-naphtoflavone (40 mg kg-1 i.p., for three consecutive days) (17) to accelerate acetaminophen-induced toxicity in rat hepatocytes. After this, hepatocytes were isolated and used. All animals received humane care and were used 
according to the criteria outlined in the "Guide for the Care and Use of Laboratory Animals" (18), which was approved by the local ethic committee in Tabriz University of Medical Sciences, Tabriz, Iran.

Different concentrations of acetaminophen were added to the cellular media to find the dose response of the drug in rat hepatocytes and the $\mathrm{LC}_{50}$ concentration (the concentration which leads to $50 \%$ cell death after $120 \mathrm{~min}$ of incubation) for the next experiments.

\section{Cell viability}

Trypan blue dye exclusion staining was used to assess the percentage of dead cells (19). Hepatocyte viability was determined at different time intervals to evaluate the effect of acetaminophen on cell viability. $\mathrm{LC}_{50}$ dose of the drug was determined and the protective effects of silafibrate and NAC against cell death induced by acetaminophen were tested. Hepatocytes were at least $85 \%$ viable before their use, as recommended in previous studies (20-27).

\section{Reactive oxygen species (ROS) formation}

To determine the extent of ROS generated during acetaminophen metabolism, 2,7-dichlorofluorescein diacetate (DCFH-DA; $1.6 \mu \mathrm{mol} \mathrm{L}^{-1}$ ) was added to the hepatocyte incubate. DCFH-DA was first hydrolysed to non-fluorescent DCFH in hepatocytes. DCFH then reacted with ROS to form the highly fluorescent DCFH. $1 \mathrm{~mL}$ (approximately $10^{6}$ cells) of hepatocyte suspension was taken and the fluorescence intensity was measured using a Jasco ${ }^{\circledR}$ FP-750 spectrofluorometer (Jasco Corporation, Tokyo, Japan) with excitation and emission wavelengths of $500 \mathrm{~nm}$ and $520 \mathrm{~nm}$, respectively (28).

\section{Lipid peroxidation measurement}

Hepatocyte lipid peroxidation was determined by measuring the amount of thiobarbituric acid reactive substances (TBARS) formed during the decomposition of lipid hydroperoxides. After treating $1 \mathrm{~mL}$ aliquots of hepatocyte suspension $\left(10^{6}\right.$ cells $\left.\mathrm{mL}^{-1}\right)$ with trichloroacetic acid $(70 \% \mathrm{w} / \mathrm{v})$ and boiling the supernatant with thiobarbituric acid $(0.8 \% \mathrm{w} / \mathrm{v})$ for $20 \mathrm{~min}$, the absorbance of the observed colour was determined using an Ultrospec ${ }^{\circledR} 2000$ UV spectrophotometer at $532 \mathrm{~nm}$ (Pharmacia Biotech Cambridge, England) (29).

\section{Mitochondrial membrane potential}

Mitochondrial membrane potential was assessed as an indicator of toxicity induced by methimazole or $\mathrm{N}$-methylthiourea. The fluorescent dye, rhodamine 123, was used as a probe to evaluate the mitochondrial membrane potential in rat hepatocytes. Samples $(1 \mathrm{~mL})$ were taken from the cell suspension at scheduled time points, and centrifuged at $1000 \mathrm{~g}$ for $1 \mathrm{~min}$. The cell pellet was then resuspended in $2 \mathrm{~mL}$ of fresh incubation medium containing $1.5 \mu \mathrm{mol} \mathrm{L}^{-1}$ rhodamine 123 and gently shaken in a thermostatic water bath at $37{ }^{\circ} \mathrm{C}$ for $10 \mathrm{~min}$. Hepatocytes were separated by centrifugation (402 $g$ for one min) and the amount of rhodamine 123 appearing in the incubation medium was measured fluorimeterically at $490 \mathrm{~nm}$ excitation and $520 \mathrm{~nm}$ emission wavelengths using a Jasco ${ }^{\circledR}$ FP-750 spectrofluorometer (30).

\section{Statistical analysis}

Results are given as mean $\pm \mathrm{SE}$ for at least three independent experiments. Statistical analysis was performed by one-way analysis of variance (ANOVA) followed by a Tukey's post hoc test. $P<0.05$ was considered as significant difference.

\section{RESULTS}

In isolated rat hepatocytes, acetaminophen hardly caused cytotoxicity and very high concentrations of the drug were needed to induce toxicity (Figure 2). Hence, to accelerate the acetaminophen-induced toxicity, we used the enzyme-induced hepatocyte model. The $\mathrm{LC}_{50}$ of acetaminophen was found to be $750 \mu \mathrm{mol} \mathrm{L}^{-1}$ (Figure 2). Different compounds (APAP in combination with proposed protective agents such as silafibrate and/or NAC) were added to the incubation medium, aimed to determine their ability to modulate the toxic response of acetaminophen. Silafibrate and/or NAC caused no significant toxicity in hepatocytes as compared to the control cells when administered alone at given concentrations.

Administration of NAC $\left(200 \mu \mathrm{mol} \mathrm{L}^{-1}\right)$ or silafibrate $\left(200 \mu \mathrm{mol} \mathrm{L}^{-1}\right)$ effectively reduced cell death (Figure 3), a significant amount of formed ROS (Figure 4), and lipid peroxidation (Figure 5) caused by acetaminophen. Acetaminophen also caused mitochondrial depolarisation in rat hepatocytes (Figure 6) and NAC or silafibrate proved to have a preventive role in this regard (Figure 6). 


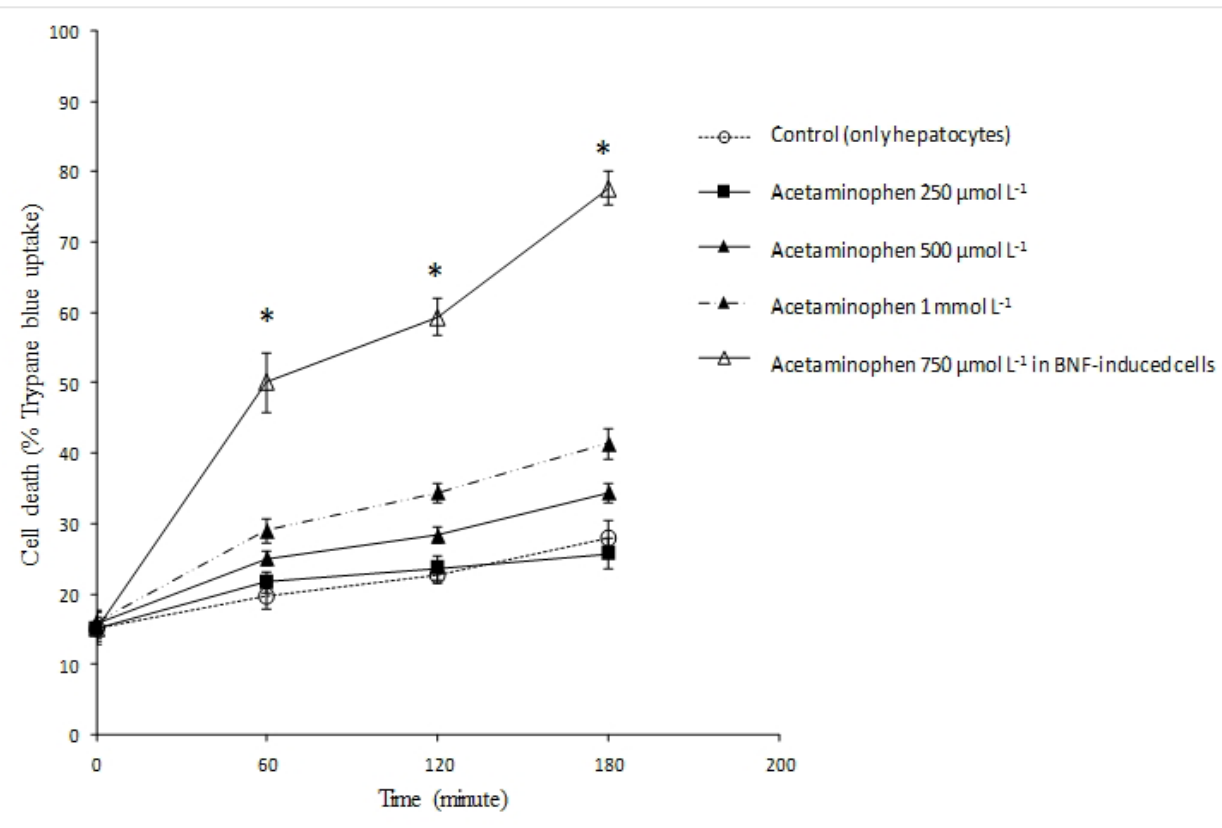

Figure 2 Dose-response of acetaminophen-induced cytotoxicity in isolated rat hepatocytes. BNF: $\beta$-naphtoflavone

* Indicates the significantly higher cell death than that of control group $(\mathrm{p}<0.05)$.

Hepatocytes cell death was not significant in the control group at different time intervals as assessed by trypan blue exclusion test.

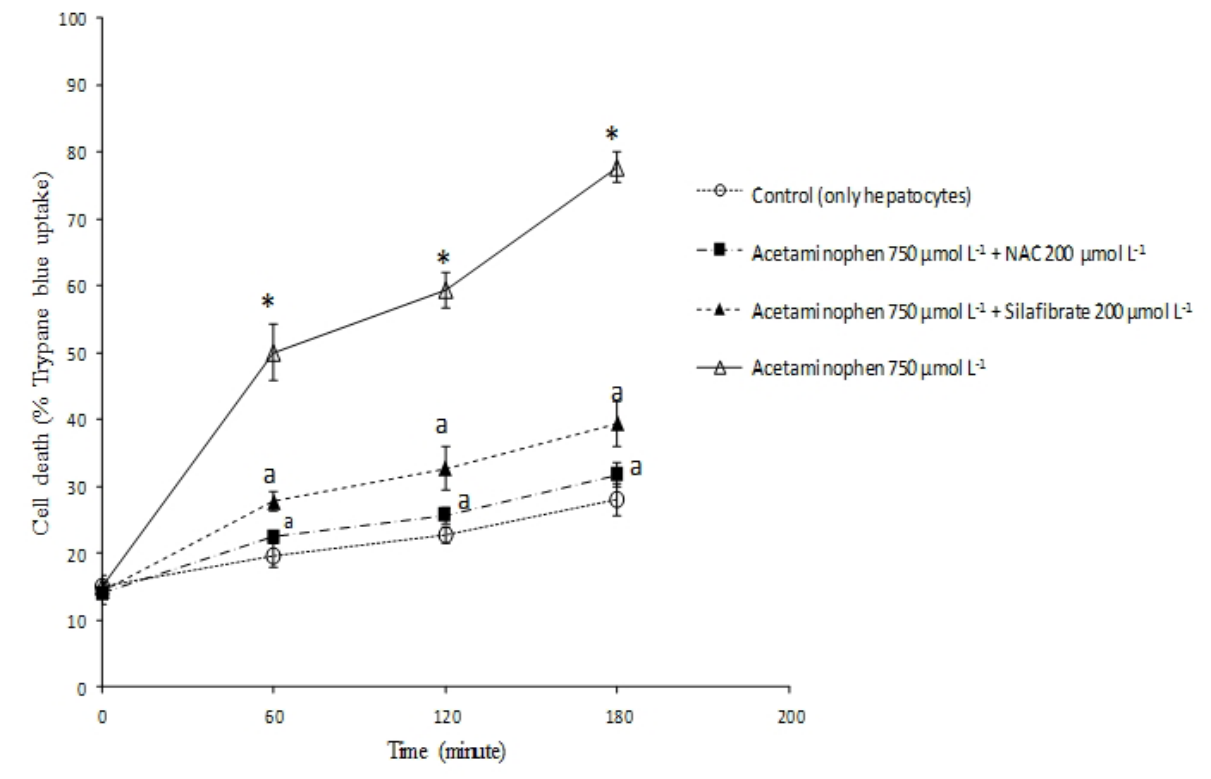

Figure 3 The protective effect of $N$-acetyl cysteine (NAC) and silafibrate against acetaminophen-induced cytotoxicity in rat hepatocytes.

"Indicates significantly higher cytotoxicity as compared to the control group $(p<0.05)$.

andicates significantly lower cytotoxicity as compared to the acetaminophen-treated group $(\mathrm{p}<0.05)$ 


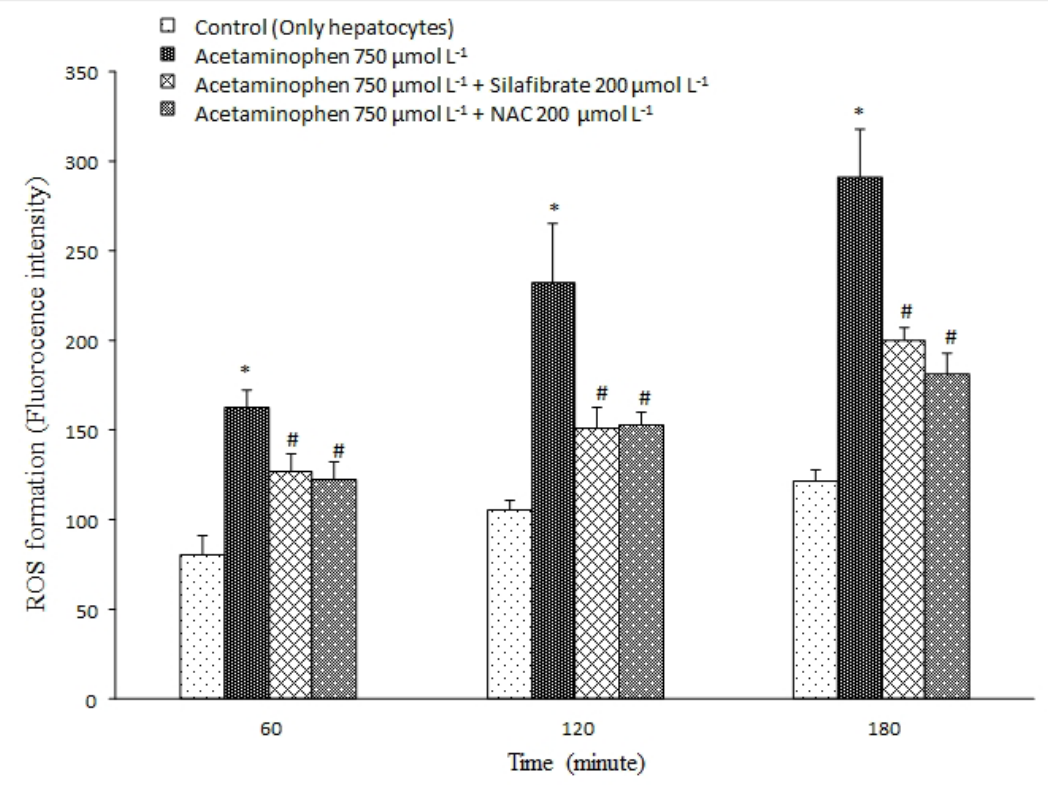

Figure 4 Acetaminophen-induced ROS formation in isolated rat hepatocytes and the effect of NAC and silafibrate administration.

"Significantly higher ROS level than control group $(\mathrm{p}<0.05)$.

\#Significantly lower ROS level than acetaminophen-treated hepatocytes $(\mathrm{p}<0.05)$

\section{DISCUSSION}

Drug-induced liver disease is the most common cause of acute liver failure, and acetaminophen accounts for the bulk of these (6). Incubation of enzyme-induced rat hepatocytes with acetaminophen caused cell death concentration-dependently. $\mathrm{The}_{50}$ for acetaminophen was $750 \mu \mathrm{mol} \mathrm{L} \mathrm{L}^{-1}$. Acetaminophen caused ROS formation, lipid peroxidation, and mitochondrial depolarisation in isolated rat hepatocytes. Administration of NAC and/or silafibrate diminished the toxic effects of acetaminophen in rat hepatocytes.

In previous studies, it has been shown that administration of PPAR ligands such as clofibrate diminished acetaminophen-induced hepatotoxicity in in vivo models (31). In addition, it has been found that PPARs null mice (PPARs -/-) were more susceptible to hepatotoxicity induced by acetaminophen (32). Furthermore, the protective effects of PPAR ligands in in vitro experiments have been shown (33).

However, the mechanism(s) underlying the hepatoprotection afforded by peroxisome proliferators have yet to be clarified, but the induction of antioxidant enzymes (34), alteration in cellular glutathione content (35), and protection against oxidative stress and inflammatory responses (36-38) are the proposed protective mechanisms. It has been found that PPAR ligands have a role in modulating oxidative stress and its deleterious consequences in different tissues such as liver (39), nervous (40), and vascular systems (41). These mechanisms could be involved in the protective properties of silafibrate against APAP-induced cytotoxicity in freshly-isolated rat hepatocytes. Currently there is no data available on the direct effect of silafibrate on ROS in biological systems. However, the chemical structure of this drug and its direct effects on reactive species might also be attributed to its protective properties in isolated rat hepatocytes. This characteristic might arise from high electron-donating nature of trimethylsilyl (TMS) group in the drug.

NAC is a standard clinical treatment against APAPinduced hepatotoxicity (42). It provides protection mainly by counteracting oxidative stress (43), and scavenging APAP reactive metabolite (44). Moreover, it replenishes hepatic glutathione reservoirs as a crucial defence barrier against xenobiotics (44).

We found that acetaminophen caused ROS formation in isolated rat hepatocytes (Figure 4). Since PPAR $\alpha$ ligands showed anti-oxidative stress properties in previous studies $(36,37,45)$, one of the mechanisms by which the drug silafibrate may protect rat hepatocytes against acetaminophen might be its effect 


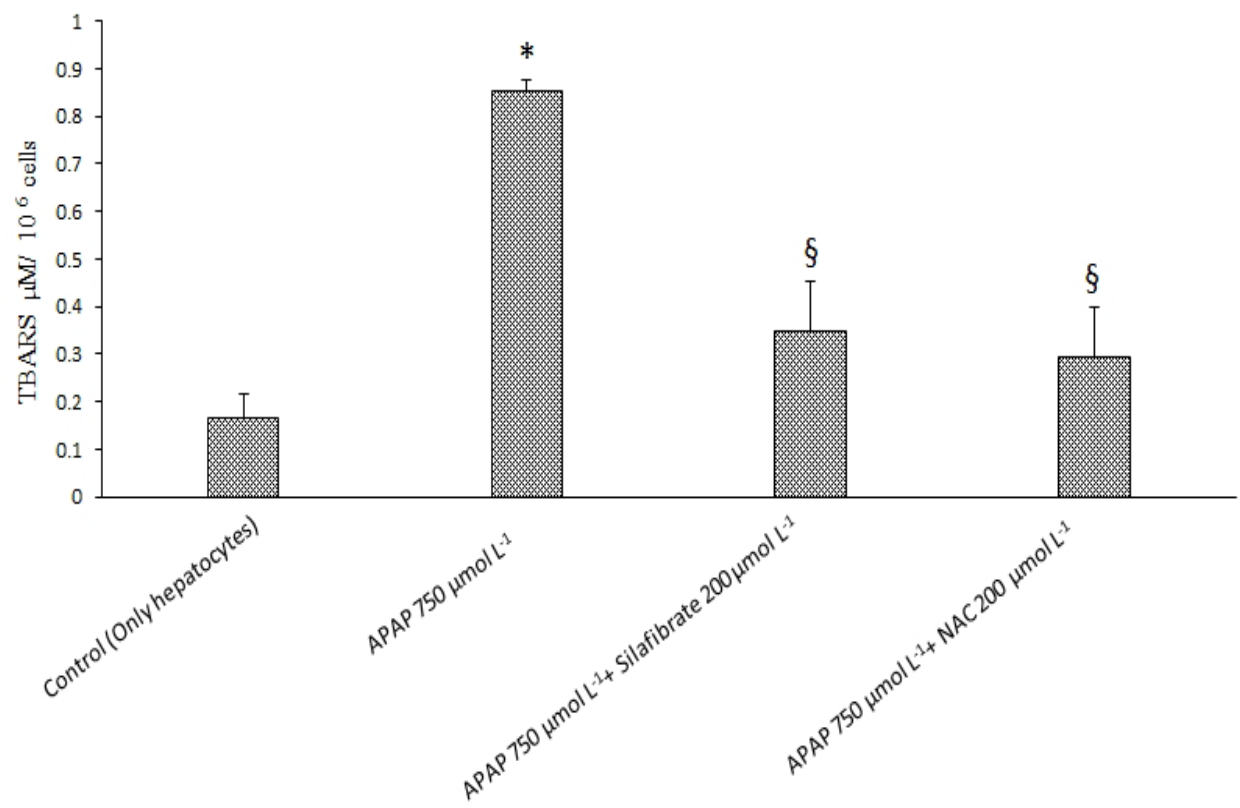

Figure 5 Lipid peroxidation caused by acetaminophen (APAP) in isolated rat hepatocytes and the protective role of $N$-acetyl cisteine (NAC) and silafibrate.

Significantly higher TBARS level than control group $(\mathrm{p}<0.05)$

$\S$ Significantly lower TBARS level than acetaminophen-treated group $(\mathrm{p}<0.05)$

on alleviating oxidative stress (Figure 4). The effect of silafibrate on lipid peroxidation induced by acetaminophen could be attributed to its effect on reducing the ROS level, which is a major cause of lipid peroxidation in cells (46).

It has been shown that oxidative stress is one of the major causes of mitochondrial damage (47). A part of silafibrate protection against acetaminophen-induced cytotoxicity may be due to its effect in preventing mitochondrial injury caused by this drug. In the current investigation we found that silafibrate as a new and more potent analogue of clofibrate (8) showed protective effects against APAP-induced cytotoxicity. These results might provide new therapeutic strategies against APAP-induced hepatotoxicity.

\section{CONCLUSION}

Silafibrate as a newly synthesised analogue of clofibrate protected rat hepatocytes against acetaminophen-induced toxicity. The protective effects of silafibrate could be attributed to its role in counteracting oxidative stress and/or its consequences such as lipid peroxidation and mitochondrial damage. The induction of antioxidant enzymes (34), alteration in cellular glutathione content (35), and protection against oxidative stress and inflammatory responses (36-38) might be involved in the cytoprotective properties of silafibrate. On the other hand, the duration of study in this in vitro model of isolated rat hepatocytes might not be sufficient to observe some silafibrate protective properties, such as induction of antioxidant enzymes. Future in vivo investigations will provide more insights on silafibrate hepatoprotective properties.

\section{Acknowledgements}

This study was carried out at Biotechnology and Drug Applied Research Centres (DARC) of Tabriz University of Medical Sciences. The authors thank Biotechnology Research centre and Drug Applied Research Center for providing financial supports and facilities to carry out this investigation. This paper was a part of the Pharm.D. thesis for Sara Nafisi and was supported technically by the students' research committee of Tabriz University of Medical Sciences, Tabriz, Iran. The authors thank students' research committee for their support.

\section{Conflict of interest}

The authors declare no conflict of interest. 


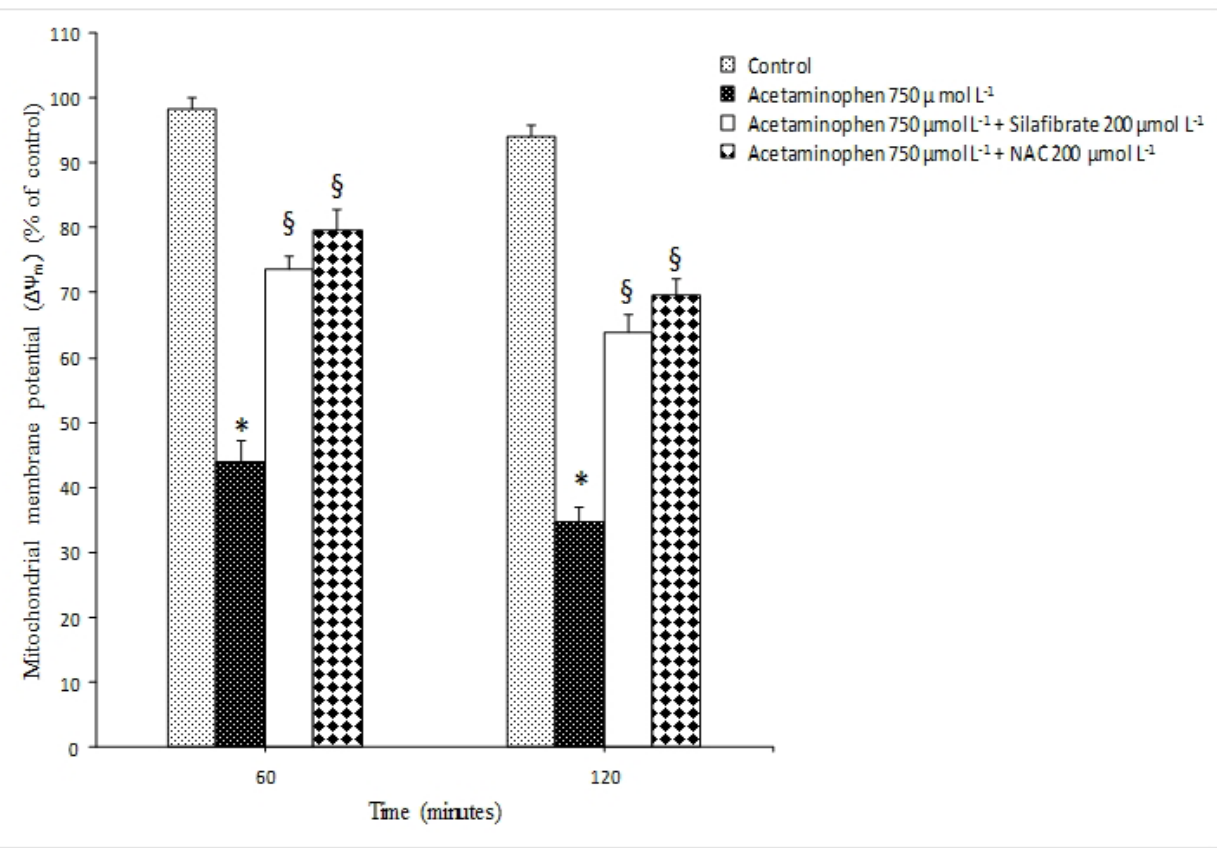

Figure 6 Acetaminophen-induced mitochondrial depolarisation. NAC and silafibrate administration effectively prevented mitochondrial injury caused by acetaminophen.

"Indicates significantly lower membrane potential as compared to the control group $(\mathrm{p}<0.05)$.

$\S$ Indicates a significantly higher membrane potential as compared to the acetaminophen-treated group $(\mathrm{p}<0.05)$

\section{REFERENCES}

1. Amar PJ, SchiffER. Acetaminophen safety and hepatotoxicity - where do we go from here? Expert Opin Drug Saf 2007:6:341-55. doi: 10.1517/14740338.6.4.341

2. Dai G, He L, Chou N, Wan YJ. Acetaminophen metabolism does not contribute to gender difference in its hepatotoxicity in mouse. Toxicol Sci 2006;92:33-41. doi: 10.1093/toxsci/ kfj192

3. James LP, Mayeux PR, Hinson JA. Acetaminophen-induced hepatotoxicity. Drug Metab Dispos 2003;31:1499-506. doi: 10.1124/dmd.31.12.1499

4. Hinson JA, Nelson SD, Mitchell JR. Studies on the microsomal formation of arylating metabolites of acetaminophen and phenacetin. Mol Pharmacol 1977;13:62533. PMID: 18660

5. Bruno M. Inhibition of protein phosphatase activity and changes in protein phosphorylation following acetaminophen exposure in cultured mouse hepatocytes. Toxicol Appl Pharmacol 1998;153:119-32. PMID: 9875306

6. Larson AM, Polson J, Fontana RJ, Davern TJ, Lalani E, Hynan LS, Reisch JS, Schiødt FV, Ostapowicz G, Shakil AO, Lee WM. Acetaminophen-induced acute liver failure: results of a United States multicenter, prospective study. Hepatology 2005;42:1364-72. doi: 10.1002/hep.20948

7. Schilling A, Corey R, Leonard M, Eghtesad B. Acetaminophen: Old drug, new warnings. Cleve Clin J Med 2010;77:19-27. doi: 10.3949/ccjm.77a.09084

8. Ziaee M, Samini M, Bolourtchian M, Ghaffarzadeh M, Ahmadi M, Eghbal MA, Khorrami A, Andalib S, MalekiDizaji N, Garjani A. Synthesis of a novel siliconized analog of clofibrate (Silafibrate) and comparison of their antiinflammatory activities. Iran J Pharm Res 2011;11:91-5.
9. Tziomalos K, Athyros VG, Karagiannis A, Mikhailidis DP. Anti-inflammatory effects of fibrates: an overview. Current M e d Chem 2009;16:676-84. doi: $10.2174 / 092986709787458416$

10. Toyama T, Nakamura H, Harano Y, Yamauchi N, Morita A, Kirishima T, Minami M, Itoh Y, Okanoue T. PPARalpha ligands activate antioxidant enzymes and suppress hepatic fibrosis in rats. Biochem Biophys Res Commun 2004;324:697704. PMID: 15474484

11. Dyrøy E, Røst TH, Pettersen RJ, Halvorsen B, Gudbrandsen OA, Ueland T, Muna Z, Müller F, Nordrehaug JE, Aukrust P, Berge RK. Tetradecylselenoacetic acid, a PPAR ligand with antioxidant, antiinflammatory, and hypolipidemic properties. Arterioscler Thromb Vasc Biol 2007;27:628-34. doi: 10.1161/01.ATV.0000255950.70774.d5

12. Chen C, Hennig GE, Whiteley HE, Corton JC, Manautou JE. Peroxisome proliferator-activated receptor alpha-null mice lack resistance to acetaminophen hepatotoxicity following clofibrate exposure. Toxicol Sci 2000;57:338-44. PMID: 11006363

13. Smilkstein MJ, Bronstein AC, Linden C, Augenstein WL, Kulig KW, Rumack BH. Acetaminophen overdose: a 48-hour intravenous N-acetylcysteine treatment protocol. Ann Emerg Med 1991;20:1058-63. PMID: 1928874

14. Heidari R, Babaei H, Eghbal MA. Ameliorative effects of taurine against methimazole-induced cytotoxicity in isolated rat hepatocytes. Sci Pharm 2012;80:987-99. doi: 10.3797/ scipharm.1205-16

15. Moldéus P, Högberg J, Orrenius S. Isolation and use of liver cells. Methods Enzymol 1978;52:60-71. PMID: 672656

16. Elbarbry FA, McNamara PJ, Alcorn J. Ontogeny of hepatic CYP1A2 and CYP2E1 expression in rat. J Biochem Mol Toxicol 2007;21:41-50. doi: 10.1002/jbt.20156 
17. Heidari R, Babaei H, Roshangar L, Eghbal MA. Effects of enzyme induction and/or glutathione depletion on methimazole-induced hepatotoxicity in mice and the protective role of N-acetylcysteine. Adv Pharm Bull 2014;4:21-8. doi: 10.5681/apb.2014.004

18. Bayne K. Revised Guide for the Care and Use of Laboratory Animals available. American Physiological Society. Physiologist 1996;39:199, 208-11. PMID: 8854724

19. Truong DH, Eghbal MA, Hindmarsh W, Roth SH, O’Brien PJ. Molecular mechanisms of hydrogen sulfide toxicity. Drug Metab Rev 2006;38:733-44. PMID: 17145698

20. Martin JW, Chan K, Mabury SA, O'Brien PJ. Bioactivation of fluorotelomer alcohols in isolated rat hepatocytes. Chem Biol Interact 2009;177:196-203. doi: 10.1016/j. cbi.2008.11.001

21. Eghbal MA, Pennefather PS, O'Brien PJ. $\mathrm{H}_{2} \mathrm{~S}$ cytotoxicity mechanism involves reactive oxygen species formation and mitochondrial depolarisation. Toxicology 2004;203:69-76. PMID: 15363583

22. Heidari R, Babaei H, Eghbal M. Mechanisms of methimazole cytotoxicity in isolated rat hepatocytes. Drug Chem Toxicol 2013;36:403-11. doi: 10.3109/01480545.2012.749272

23. Mehta R, Wong L, O’Brien PJ. Cytoprotective mechanisms of carbonyl scavenging drugs in isolated rat hepatocytes. Chem Biol Interact 2009;178:317-23. doi: 10.1016/j. cbi.2008.10.026

24. Banach MS, Dong Q, O'Brien PJ. Hepatocyte cytotoxicity induced by hydroperoxide (oxidative stress model) or glyoxal (carbonylation model): prevention by bioactive nut extracts or catechins. Chem Biol Interact 2009;178:324-31. doi: 10.1016/j.cbi.2008.10.003

25. Feng CY, Wong S, Dong Q, Bruce J, Mehta R, Bruce WR, O'Brien PJ. Hepatocyte inflammation model for cytotoxicity research: fructose or glycolaldehyde as a source of endogenous toxins. Arch Physiol Biochem 2009;115:105-11. doi: 10.1080/13813450902887055

26. Niknahad H, O'Brien PJ. Mechanism of sulfite cytotoxicity in isolated rat hepatocytes. Chem Biol Interac 2008; 174:14754. doi: 10.1016/j.cbi.2008.05.032

27. Heidari R, Babaei H, Eghbal MA. Amodiaquine-induced toxicity in isolated rat hepatocytes and the cytoprotective effects of taurine and/or N-acetyl cysteine. Res Pharm Sci 2014;9:97-105.

28. Abdoli N, Heidari R, Azarmi Y, Eghbal MA. Mechanisms of the statins cytotoxicity in freshly isolated rat hepatocytes. J Biochem Mol Toxicol 2013;27:287-94. doi: 10.1002/ jbt. 21485

29. Heidari R, Babaei H, Eghbal MA. Cytoprotective effects of organosulfur compounds against methimazole-induced toxicity in isolated rat hepatocytes. Adv Pharm Bull 2013;3:135-42. doi: 10.5681/apb.2013.023

30. Heidari R, Babaei H, Eghbal MA. Cytoprotective effects of taurine against toxicity induced by isoniazid and hydrazine in isolated rat hepatocytes. Arh Hig Rada Toksikol 2013;64:201-9. doi: 10.2478/10004-1254-64-2013-2297

31. Manautou JE, Hoivik DJ, Tveit A, Hart SGE, Khairallah EA, Cohen SD. Clofibrate pretreatment diminishes acetaminophen's selective covalent binding and hepatotoxicity. Toxicol Appl Pharmacol 1994;129:252-63. PMID: 7992315

32. Chen C, Hennig GE, Whiteley HE, Corton JC, Manautou JE. Peroxisome proliferator-activated receptor alpha-null mice lack resistance to acetaminophen hepatotoxicity following clofibrate exposure. Toxicol Sci 2000;57:338-44. PMID: 11006363

33. Nicholls-Grzemski FA, Calder IC, Priestly BG, Burcham PC. Clofibrate-induced in vitro hepatoprotection against acetaminophen is not due to altered glutathione homeostasis. Toxicol Sci 2000;56:220-8. doi: 10.1093/toxsci/56.1.220

34. Chen C, Hennig GE, Whiteley HE, Manautou JE. Protection against acetaminophen hepatotoxicity by clofibrate pretreatment: role of catalase induction. J Biochem Mol Toxicol 2002;16:227-34. PMID: 12439864

35. Antonenkov VD, Gusev VA, Panchenko LF. Effect of clofibrate treatment on glutathione content and the activity of the enzymes related to peroxide metabolism in rat liver and heart. Int J Biochem 1987;19:187-92. doi: 10.1016/0020$711 X(87) 90330-2$

36. Camps J, García-Heredia A, Rull A, Alonso-Villaverde C, Aragonès G, Beltrán-Debón R, Rodríguez-Gallego E, Joven $J$. PPARs in regulation of paraoxonases: control of oxidative stress and inflammation pathways. PPAR Research 2012;2012:616371. doi: 10.1155/2012/616371

37. Gelosa P, Banfi C, Gianella A, Brioschi M, Pignieri A, Nobili E, Castiglioni L, Cimino M, Tremoli E, Sironi L. Peroxisome proliferator-activated receptor $\alpha$ agonism prevents the oxidative stress and inflammatory processes involved in brain and renal damage in stroke-prone rats. J Pharmacol Exp Therap 2010;335:324-31. doi: 10.1124/jpet.110.171090

38. Devchand PR, Ziouzenkova O, Plutzky J. Oxidative stress and peroxisome proliferator-activated receptors reversing the curse? Circ Res 2004;95:1137-9. doi: 10.1161/01. RES.0000151331.69399.b2

39. Marra F, Efsen E, Romanelli RG, Caligiuri A, Pastacaldi S, Batignani G, Bonacchi A, Caporale R, Laffi G, Pinzani M, Gentilini P. Ligands of peroxisome proliferator-activated receptor $\gamma$ modulate profibrogenic and proinflammatory actions in hepatic stellate cells. Gastroenterology 2000;119:466-78. PMID: 10930382

40. Fruchart JC, Bastide M. PPAR: a new pharmacological target for neuroprotection in stroke and neurodegenerative diseases. Biochem SocTrans 2006;34:1341-6. PMID: 17073815

41. Hwang J, Kleinhenz DJ, Lassègue B, Griendling KK, Dikalov S, Hart CM. Peroxisome proliferator-activated receptor- $\gamma$ ligands regulate endothelial membrane superoxide production. Am J Physiol Cell Physiol 2005;288:C899-905. PMID: 15590897

42. Bebarta VS, Kao L, Froberg B, Clark RF, Lavonas E, Qi M, Delgado J, McDonagh J, Arnold T, Odujebe O, O’Malley G, Lares C, Aguilera E, Dart R, Heard K, Stanford C, Kokko J, Bogdan G, Mendoza C, Mlynarchek S, Rhyee S, Hoppe J, Haur W, Tan HH, Tran NN, Varney S, Zosel A, Buchanan J, Al-Helial M. A multicenter comparison of the safety of oral versus intravenous acetylcysteine for treatment of acetaminophen overdose. Clin Toxicol 2010;48:424-30. doi: 10.3109/15563650.2010.486381

43. Reid AB, Kurten RC, McCullough SS, Brock RW, Hinson JA. Mechanisms of acetaminophen-induced hepatotoxicity: role of oxidative stress and mitochondrial permeability transition in freshly isolated mouse hepatocytes. J Pharmacol Exp Therap 2005;312:509-16. doi: 10.1124/jpet.104.075945

44. Jones AL. Mechanism of action and value of N-acetylcysteine in the treatment of early and late acetaminophen poisoning: 
a critical review. J Toxicol Clin Toxicol 1998;36:277-85. PMID: 9711192

45. Rodrigues GA, Maurier-Mahé F, Shurland D-L, McLaughlin A, Luhrs K, Throo E, Delalonde-Delaunay L, Pallares D, Schweighoffer F, Donello J. Differential effects of PPARgamma ligands on oxidative stress-induced death of retinal pigmented epithelial cells. Invest Ophthalmol Vis Sci 2011;52:890-903. doi: 10.1167/iovs.10-5715
46. Blokhina O, Virolainen E, Fagerstedt KV. Antioxidants, oxidative damage and oxygen deprivation stress: a review. Ann Botany 2003;91:179-94. doi: 10.1093/aob/mcf118

47. Kowaltowski AJ, Vercesi AE. Mitochondrial damage induced by conditions of oxidative stress. Free Radic Biol Med 1999;26:463-71. PMID: 9895239 


\title{
Sažetak
}

Citoprotektivni učinci silafibrata, novosintetiziranog silikoniranog derivata klofibrata protiv acetaminofenom izazvane toksičnosti u izoliranim hepatocitima štakora

\begin{abstract}
Acetaminofen (N-acetil-para-aminofenol, APAP) često je korišteni antipiretik i analgetik koji može izazvati oštećenja jetara. Na modelu izoliranih hepatocita štakora istražili smo toksične učinke APAP-a i protektivne učinke silafibrata i N-acetilcisteina (NAC). Hepatociti su izolirani iz mužjaka štakora soja Sprague-Dawley perfuzijom jetara i uvođenjem enzima kolagenaze putem portalne vene. Ta se tehnika zasniva na perfuziji jetara kolagenazom nakon uklanjanja kalcijevih iona $\left(\mathrm{Ca}^{2+}\right)$ kelatorom. Stanice su tretirane različitim koncentracijama APAP-a, silafibrata i NAC-a. Kao markeri toksičnosti mjereni su smrt stanica, stvaranje reaktivnih kisikovih vrsta (ROS), lipidna peroksidacija i depolarizacija mitohondrija. Primjena APAP-a u štakora izazvala je stvaranje ROS-ova i lipidnu peroksidaciju. APAP je uzrokovao depolarizaciju mitohondrija u izoliranim stanicama. Primjena silafibrata $(200 \mu \mathrm{mol} \mathrm{L}-1)$ i/ili NAC-a $\left(200 \mu \mathrm{mol} \mathrm{L}^{-1}\right)$ smanjila je stvaranje ROS-a, lipidnu peroksidaciju i depolarizaciju mitohondrija uzrokovanu APAP-om. Utvrdili smo da je citotoksičnost APAP-a posredovana oksidativnim stresom. Nadalje, čini se da su mitohondriji ciljni stanični organeli za oštećenja hepatocita izazvanih APAP-om. Moguće je da su protektivna svojstva silafibrata i/ili NAC-a protiv APAP-om induciranog oštećenja jetara uključivala i indukciju antioksidacijskih enzima, zaštitu od oksidativnog stresa i upalnih odgovora te promjenu razine staničnoga glutationa.
\end{abstract}

KLJUČNE RIJEČI: fibrati; mitohondriji; oksidativni stres; oštećenje jetara izazvano lijekom; reaktivne kisikove vrste (ROS)

\section{CORRESPONDING AUTHOR:}

\author{
Mohammad Ali Eghbal \\ Tabriz University of Medical Sciences \\ Pharmacology and Toxicology Department \\ School of Pharmacy \\ Tabriz, Iran \\ E-mail:m.a.eghbal@hotmail.com
}

